\title{
Review \\ Multifunctional roles of insulin-like growth factor binding protein 5 in breast cancer
}

\author{
Mustafa Akkiprik1, Yumei Feng ${ }^{2,3}$, Huamin Wang ${ }^{4}$, Kexin Chen ${ }^{5}$, Limei Hu ${ }^{4}$, Aysegul Sahin 4 , \\ Savitri Krishnamurthy ${ }^{4}$, Ayse Ozer ${ }^{1}$, Xishan $\mathrm{Hao}^{2,3,5}$ and Wei Zhang ${ }^{4}$
}

\begin{abstract}
1Department of Medical Biology, Marmara University, School of Medicine, 34668 Istanbul, Turkey
2Department of Biochemistry and Molecular Biology, Tianjin Medical University Cancer Institute and Hospital, Tianjin 300060, China

${ }^{3}$ Breast Cancer Prevention and Treatment Key Lab of Ministry of Education, Tianjin Medical University Cancer Institute and Hospital, Tianjin 300060, China

${ }^{4}$ Department of Pathology, Unit 85, The University of Texas MD Anderson Cancer Center, 1515 Holcombe Boulevard, Houston, TX 77030, USA

${ }^{5}$ Department of Epidemiology and Biostatistics, Tianjin Medical University Cancer Institute and Hospital, Tianjin 300060, China
\end{abstract}

Corresponding author: Wei Zhang, wzhang@mdanderson.org

Published: 11 August 2008

This article is online at http://breast-cancer-research.com/content/10/4/212

(c) 2008 BioMed Central Ltd
Breast Cancer Research 2008, 10:212 (doi:10.1186/bcr2116)

IGF-I and IGF-II. The IGFs have been well documented to play a crucial role in cellular growth, differentiation, and apoptosis $[5,6]$. The IGF pathway has been shown to be activated in many cancer types, including breast cancer [7-9]. IGF binds to two types of receptors, IGF-IR and IGF-IIR, on cell membranes, and activates the tyrosine kinase pathway downstream $[4,10]$. Binding of IGFBP proteins with IGF has been shown to either positively or negatively regulate the binding of IGFs to their receptors [1], thus directly affecting the IGF signaling pathways.

Numerous studies, however, have found that IGFBPs also function independently of the IGF signaling pathway. IGFBPs may interact with proteins other than IGFs, may be cleaved, may bind to their own receptor on the membrane, and may locate both extracellularly and intracellularly [11]. Importantly, there is increasing evidence that IGFBP-2, IGFBP-3, and IGFBP-5 are important players in the phenotypes of various cancers $[2,12,13]$. Pertinent to the present review, IGFBP-5 has been associated with breast metastasis $[9,14]$.

In the present article, we review literature reports on the functions and regulation of IGFBP-5, and particularly their potential role in breast cancer development and progression.

\section{IGFBP-5 gene and protein}

IGFBP-5 was first cloned in 1993 [15], and its genomic structure was characterized in 1994 by Allander and colleagues [16]. The IGFBP-5 gene has a length of $33 \mathrm{~kb}$ and is located on chromosome 2 in humans. This gene, which

$\mathrm{ECM}=$ extracellular matrix; $\mathrm{ER}=$ estrogen receptor; IGF = insulin-like growth factor; IGFBP = insulin-like growth factor binding protein; NF = nuclear factor; NLS = nuclear localization sequence; $\mathrm{PCR}=$ polymerase chain reaction; RASSF1C $=$ Ras-associated domain family 1 protein; RT = reverse transcriptase; $\mathrm{TNF}=$ tumor necrosis factor. 


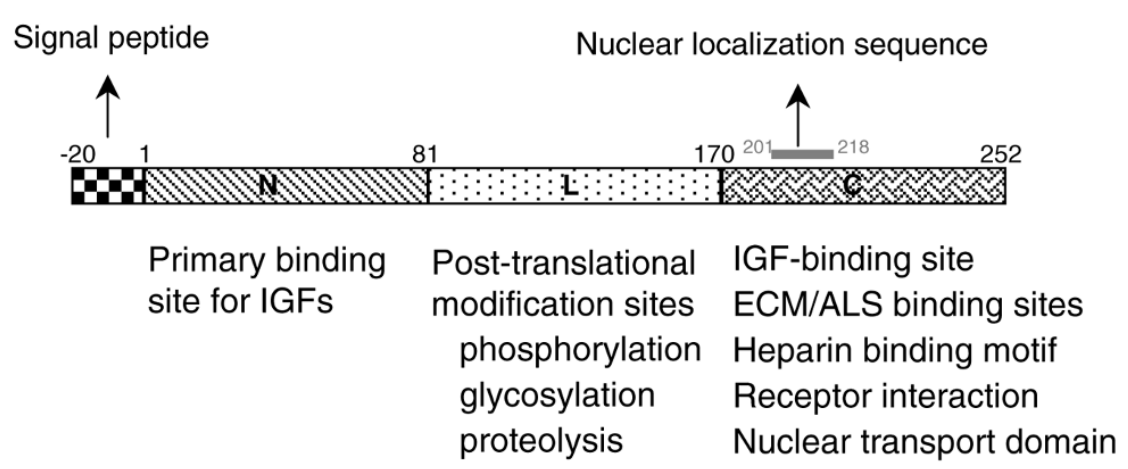

Domain structure of insulin-like growth factor binding protein 5 and potential functional effects. ALS, acid-labile subunit; ECM, extracellular matrix; IGF, insulin-like growth factor.

has four exons, encodes a soluble protein of approximately $29 \mathrm{kDa}$ expressed in various types of tissues in humans. The IGFBP-5 gene is located on the same chromosome as the IGFBP-2 gene but is oriented in a tail-to-tail fashion (opposite direction of transcription). The IGFBP-1 and IGFBP-3 genes also show the same structural orientation on chromosome 7 [17]. These structural relationships between IGFBP genes suggest that these genes developed after duplication of an ancestral IGFBP gene.

IGFBPs share a common domain organization. A schematic representation of the IGFBP-5 domain structure is shown in Figure 1. IGFBP-5 has several features that suggest it is a key component of the IGF system. IGFBP- 5 contains a leader or signal peptide (first 20 residues) that allows its secretion from the cytoplasm to the extracellular matrix (ECM).

\section{N domain}

The IGFBP-5 protein contains 18 conserved cysteine residues, of which 12 are located in the $\mathrm{N}$-terminal domain and the others in the $\mathrm{C}$-terminal domain. Using nuclear magnetic resonance spectroscopy, Kalus and colleagues examined the $\mathrm{N}$-terminal fragments of IGFBP-5 [18]. They found that the primary binding site for IGFs is located between Ala40 and lle92, termed mini-IGFBP-5, which has a rigid globular structure consisting of a centrally located three-stranded antiparallel $\beta$-sheet and contains two internal disulfide bonds (Cys47-Cys60 and Cys54-Cys80). The main residues for IGF-binding sites are Val49, Tyr50, Pro62, and Lys68 to Leu75 located in the mini-IGFBP-5 sequence. Mutagenesis studies have shown that residues Lys68, Pro69, Leu70, Leu73, and Leu74 in the N-terminal region of IGFBP-5 are the most critical amino acids for high-affinity binding to IGF-I [19].

\section{L domain}

The midregion of IGFBP-5 ( $\mathrm{L}$ domain) is less conserved compared with the $\mathrm{N}$ and $\mathrm{C}$ domains and contains posttranslational modification sites for glycosylation, phosphory- lation, and proteolysis. These post-transcriptional modifications might play important roles in protein interactions, the protein half-life, and the proteolysis potential. Structural characterization studies have revealed O-glycosylation [20,21] and serine phosphorylation sites for IGFBP-5 [22]. The functional role of these modifications is unclear, but it has been postulated that these modifications may affect the interaction with IGFs, the acid-labile subunit, and cell surface or matrix components [23]. Proteolytic degradation of IGFBPs into fragments reduces their affinity for IGFs, increases the concentration of free IGFs at the cell surface, and activates the IGF receptor signaling pathway.

Most of the proteolytic sites of IGFBP-5 determined so far are located in the $L$ domain. Several different proteases that specifically degrade IGFBP-5 have been identified [24]. Serine proteases (complement protein 1s) [25], metalloproteinases (MMP-1) [26], ADAM 12S [27], PAPP-A2 [28] and cathepsins (cathepsin D) [29] are the members of the IGFBP-5-degrading proteinases. Through the functions of these proteases, IGFBP-5 degradation can be regulated in a tissue-specific manner.

\section{C domain}

Another critical and functionally effective domain of IGFBP-5 is its $\mathrm{C}$-terminal domain. This domain contains a region (amino acids 201 to 218) that shares strong sequence homology with a previously identified nuclear localization sequence (NLS) [30]. Among the six IGFBPs, only IGFBP-3 and IGFBP-5 have a nuclear localization sequence. The NLS is located between amino acids 215 and 232 for IGFBP-3. Studies from Schedlich and her coworkers have demonstrated the importance of the NLS of IGFBP-5 in cytoplasmic and nuclear trafficking [31,32]. They observed nuclear localization using fluorescently labeled IGFBP-3 and IGFBP-5 in the T47D cell line [31]. In addition, these researchers showed that transportation of IGFBP-5 depends on its NLS and is not affected by blocking of the receptor-mediated 
endocytosis. More recently, the same group showed that importin- $\beta$ binds IGFBP-5 and is responsible for the nuclear transport of IGFBP-5 [32]. More in-depth studies will be needed to understand the effect of IGFBP-5 cellular localization on its physiological functions and the role of this spatial regulation in breast cancer pathobiology.

Recently, Jurgeit and colleagues studied nuclear and cytoplasmic trafficking and localization of IGFBP-5 in the T47D breast cancer cell line and in paraffin sections of involuting mammary glands [33]. To evaluate cellular localization of IGFBP-5, they used different mutant forms of the protein, such as signaling peptide and NLS deletions, in addition to the wild-type secreted form and the recombinant IGFBP-5 protein. They found that cellular localization of IGFBP-5 is strictly affected by secretion and the nonsecreted form of the protein. Although IGFBP-5 could not be localized in the nucleus under in vivo conditions, only the signaling peptide mutant and the signaling peptide plus NLS mutant forms were detected in the nuclear compartment and in both cellular compartments, respectively. Their study emphasizes the importance of intracellular trafficking of IGFBP-5 and its critical regions in mammary epithelium.

The NLS of IGFBP-5 also contains a heparin-binding motif (consensus sequence BBBXXB, where $B$ is a basic amino acid and $X$ is any amino acid) between amino acids 206 and 211 (KRKQCK). The heparin-binding motif binds to glycosaminoglycan. A stimulatory effect of the IGFBP-5 heparinbinding motif on the migration of mesangial cells has been shown by Abrass and colleagues, who also showed that this effect is inhibited by heparin [34]. In addition to the NLS and the heparin-binding motif, the C-terminal domain of IGFBP-5 also carries IGF-binding sites. Allan and coworkers have recently shown that mutations of basic residues in the NLS of IGFBP-5 significantly reduce the affinity for IGF-I [35]. These studies shed light on the importance of the NLS of IGFBP-5 on its functional spectrum.

\section{Transcriptional regulation of IGFBP-5 expression}

T47D breast cancer cells are IGF responsive because they express IGF-IR and produce IGFBPs. When these cells were incubated with IGF-I, a significant increase in IGFBP-5 in the conditioned medium was observed [36]. In contrast, IGF-I treatment only slightly increased the level of IGFBP-5 in the cellular extract. IGF-I treatment had no significant effect on the IGFBP-5 mRNA level in T47D breast cancer cells [36]. In addition, blocking the IGF-IR using a specific monoclonal antibody did not change the results, suggesting that IGF-I regulates IGFBP-5 through both receptor-dependent and receptor-independent mechanisms [36].

Kou and colleagues analyzed the promoter sequence of IGFBP-5 by luciferase assays in the mouse C2 myoblast cell line, and found that 156 nucleotides upstream of the start codon is critical for the promoter activity of IGFBP-5 [37,38]. Duan and Clemmons later demonstrated that the binding sites for transcription factor AP-2 are located 5 ' from the TATA box [39]. AP-2 regulates IGFBP-5 gene expression through binding the proximal GCCNNNGGG-like sequences in fibroblasts. They also found that this region of the IGFBP-5 promoter is responsible for the cAMP responsiveness of this gene. In addition, McCarthy and colleagues showed that prostaglandin $E_{2}$ enhances IGFBP-5 gene expression in primary fetal rat osteoblast cultures through AP-2 sites [40].

Gabbitas and colleagues showed that cortisol decreases IGFBP-5 transcription, and found that the region responsive to cortisol is from base pairs -70 to -22 and that E-box binding proteins or c-myb-related nuclear factors may be involved in its regulation [41]. These findings were confirmed by another group: Ji and colleagues reported that potential cis-acting elements, including CAAT/enhancer-binding protein and NF-1-related sequences, could increase IGFBP-5 promoter activity in prostaglandin $\mathrm{E}_{2}$-activated osteoblasts [42]. Yeh and colleagues reported a suppressive effect of osteogenic protein-1 on IGFBP-5 expression at the transcriptional level, and found that this osteogenic protein-1 site was located within the E-box/c-myb-like motif in fetal rat calvaria cells $[43,44]$. Analysis of the IGFBP-5 promoter region by Tanno and colleagues revealed myb-binding sites and also serine/threonine kinase-binding-responsive elements in this part of the promoter region [45]. They suggested that myb-independent transactivation of the IGFBP-5 promoter in neuroblastoma cells is via the phosphoinositide 3-kinase/ serine-threonine kinase pathway, probably mediated by IGF-1R-dependent signals.

IGFBP-5 expression is regulated by a number of other treatments. Retinoic acids are potent growth-inhibitory and antiapoptotic agents for both normal cells and tumor cells [46]. Retinoic acid treatment upregulates IGFBP-5 expression in different cell lines, including neuroblastoma [47], cervical cancer [48], and osteoblastic cells [49]. Cesi and colleagues reported that the CAAT/enhancer-binding proteinresponsive element had a repressive effect on IGFBP-5 transcription in neuroblastoma cells [47]. On the other hand, studies using the breast cancer cell line T47D [36] and the prostate cancer cell line PC-3 [50] found that treatment with retinoic acid reduced the IGFBP-5 level. This difference could possibly be due to the cell type and context dependency.

Vitamin D regulates calcium homeostasis and also has potential antiapoptotic activities [51]. The effects of vitamin D are mediated through its receptor (VDR), which is known to be a ligand-activated transcription factor and which regulates target genes. The receptor also binds another nuclear steroid receptor, retinoid $X$ receptor, and generates heterodimers [52]. Rozen and colleagues found that vitamin D and its compounds increased the expression of IGFBP-5 in con- 
ditioned medium and also had the same effect on its mRNA level in the MCF-7 breast cancer cell line [53]. It is possible that IGFBP-5 contributes to the antiproliferative action of vitamin $D$ in this breast cancer cell line.

\section{Interactions of IGFBP-5 with other biomolecules}

IGFBP-5 has been shown to interact specifically with a number of proteins, especially the ECM proteins through the basic carboxyl-terminal domain of the protein. Some of these proteins are IGF-dependent proteins, such as the acid-labile subunit [54,55] and glycosaminoglycan [56-58]. Other proteins are IGF-independent proteins, such as fibronectin [59], osteopontin [60], four-and-a-half LIM protein 2 [61], human plasminogen activator inhibitor-1 [62], thrombospondin-1 [60], vitronectin [63,64], importin- $\beta$ [32], and Rasassociated domain family 1 protein (RASSF1C) [65]. These interactions regulate IGF bioavailability and half-life, and potentiate the physiological roles of IGF.

IGFBP-5 binds to ECM components, such as type III and type IV collagen, laminin, and fibronectin [66]. This interaction reduces the affinity of IGFBP-5 for IGF-I and potentiates growth-stimulatory effects of IGF-I on fibroblasts. Arai and colleagues investigated the role of glycosaminoglycans in effecting the interaction of the IGF-I and IGFBP complexes [57]. They found that heparin, heparin sulfate, and dermatan sulfate binding to IGFBP-5 resulted in conformational changes in IGFBP-5 that lowered its affinity for IGF-I and inhibited the IGF-I:IGFBP-5 interaction. Glycosaminoglycans prevent degradation of IGFBP-5, possibly through the inhibition of some specific proteases [56]. The heparin-binding motif of IGFBP-5 affects interaction with glycosaminoglycan components of the ECM. Synthetic peptide models and site-directed mutagenesis studies have shown that amino acids between 201 and 218 in the heparin-binding domain of IGFBP-5 are critical residues for these interactions [57,67]. The same domain also has migratory induction effects and IGF-binding sites [34,68].

Most circulating IGFs are carried with IGFBPs and a liverderived glycoprotein known as the acid-labile subunit. Twigg and Baxter observed that IGFBP-5 is involved in forming a ternary complex with IGFs and the acid-labile subunit [54]. Among the six well-characterized IGFBPs, only IGFBP-3 and IGFBP-5 have the ability to constitute the complex structure. Interaction sites between IGFBP-5 and the acid-labile subunit have been identified on the carboxyl-terminal domain of IGFBP-5 within amino acids 201 to 218 [55]. The central domain of IGFBP-5 can bind to the acid-labile subunit with much less potency than full-length recombinant human IGFBP-5 [69].

Nam and colleagues found that another ECM protein interacts with IGFBP-5 [60]. Thrombospondin-1 and osteopontin bind to IGFBP-5 and modulate IGF-I-stimulated cell growth. Moralez and colleagues conducted a detailed functional analysis of the interaction between IGFBP-5 and thrombospondin-1 on IGF-I actions [70]. They found that IGFBP-5 inhibits the binding of thrombospondin-1 to integrinassociated protein, and this leads to a disturbance of the cellular response to IGF-I. Plasminogen activator inhibitor- 1 is another ECM component that interacts with IGFBP-5 [62]. Plasminogen activator inhibitor-1 interaction with IGFBP-5 protects the protein from proteolysis. Potential interaction between IGFBP-5 and vitronectin and its IGF-I-stimulated biological effects has been investigated in smooth muscle cells and in MCF-7 breast cancer cells [63,71]. These two studies found that IGFBP-5 binds vitronectin and enhances the migration response to IGF-I. A complex of IGF-I-IGFBP5 -vitronectin also increased cell migration and protein synthesis in HaCAT keratinocyte cells [64]. Complex formation between fibronectin and IGFBP-5 does not directly affect the binding of IGF-I to IGFBP-5 because the binding sites do not overlap; however, fibronectin increases proteolytic degradation of IGFBP-5 [59]. After this interaction, IGFdependent action on cell migration is abolished in mouse embryonic cells. This different effect of the interaction on IGFBP-5 protein half-life may depend on the profile of ECM and may be cell-type specific.

There are also different types of proteins that interact with IGFBP-5 and determine its IGF-independent effects on cellular actions. Some of these interacting proteins are importin- $\beta$, four-and-a-half LIM protein 2, and RASSF1C. IGFBP-5 can transport into the nucleus using a NLSdependent pathway mediated by the importin- $\beta$ nuclear transport factor [32]. Yeast two-hybrid data provide evidence that IGFBP-5 interacts with the transcriptional coactivator protein four-and-a-half LIM protein 2 [61]. These authors found that these two proteins colocalize into the nucleus in U2 human osteosarcoma cells. Further studies are needed to determine the functional role of this interaction. Another novel interaction with IGFBP-5 has been demonstrated with RASSF1C, a member of the RASSF1 gene products, by the same yeast two-hybrid methodology [65]. This interaction contributes to mediating the effects of IGFBP-5 on extracellular signal-regulated kinase phosphorylation and osteoblast cell proliferation.

\section{Involvement of IGF and IGFBP-5 in mammary gland development and involution}

Mammary gland differentiation is a good model for understanding the roles of IGFBPs in cancer development. The growth, development, and regression of the mammary gland during the cycle of pregnancy, lactation, and involution are regulated by several factors. Hormones, growth factors, and the ECM are involved in these processes. One of the most critical and interesting systems involved in the regulation of mammary epithelial cell function is the IGF axis [72,73]. IGFs work coordinately with growth hormone to enhance its developmental effects on the mammary gland. Generally, all six IGFBPs are present on the mouse mammary gland, and 
IGFBP-3 and IGFBP-5 are expressed most prominently in pregnant gland tissue [74]. The expression level of IGFBP-5 increases dramatically during the early stages of involution, and an apoptotic relationship has been shown by several laboratories [75-79].

Involution involves two distinct phases. The first phase is reversible and controlled by apoptosis. The second phase is irreversible and is characterized by remodeling of the lobuloalveolar architecture, which is regulated by proteases and macrophages [80]. Although many critical genes and pathways - such as NF- $\kappa B$, phosphoinositide (3)-kinase, Stat3, transforming growth factor beta [81], matrix metalloproteinase, and the TIMP family [80] - are involved in apoptotic events of involution, the IGFBP- 5 gene has recently been shown to play a crucial role in both stages. The increases in the IGFBP-5 level are regulated by prolactin [77], which plays an essential role in the suppression of IGFBP-5 secretion. There is good homeostasis between regulation of the IGF axis and involution events. Mechanistic studies have shown that growth hormone increases IGF-I synthesis and that prolactin represses IGFBP-5 expression $[78,82]$. When prolactin levels are reduced by weaning, Stat3 is activated and the IGFBP-5 level then increases. The findings suggest that an enormous increase of IGFBP-5 in the involution phase induces mammary epithelial apoptosis [83].

Lochrie and colleagues recently offered another hypothesis [84]: IGFBP-5 expression has a dual regulation during both differentiation and apoptosis in the mammary gland, and there is a spatial regulation of IGFBP-5 function in breast tissue differentiation and cancer progression. It is conceivable that the regulation of IGFBP-5 subcellular localization is a key mechanism in controlling IGFBP-5 function. Ning and colleagues recently used IGFBP-5 knockout mice to show the in vivo effects of IGFBP-5 in mammary gland development [85]. They found that IGFBP-5 is not essential to normal growth but does have an important role in mammary gland involution and also can regulate mammary gland differentiation by different mechanisms.

\section{Role of IGFBP-5 in breast cancer}

Although studies based on breast cancer cell lines have yielded conflicting data regarding the function of IGFBP-5, these findings nevertheless offer important insight into the molecular mechanisms and possible role of IGFBP-5 in breast cancer. Such information will provide new ideas for clinical applications and routine usage in breast cancer therapy, prognosis, and early diagnosis. Most studies related to IGFBP-5 focus on its apoptotic potential, its interaction with other proteins, cell migration abilities, enhancement of cell growth, and cellular trafficking $[2,11]$.

The IGF-I signaling pathway is activated in breast cancer and activates two main downstream signal transduction pathways: the IRS-1/phosphoinositide 3-kinase/serine-threonine kinase pathway and the Ras/mitogen-activated protein kinase/ extracellular signal-regulated kinase pathway (Figure 2). These two signaling cascades, which are the most critical pathways in cancer progression, are responsible for the aggressive phenotype of breast cancer [86-88]. IGFBP-5 can regulate these pathways by binding with IGF-I - this is known as the IGF-dependent effect of the IGF binding proteins (Figure 3a). In addition to its IGF-dependent function, IGFBP-5 has also unique functions that are IGF independent. The IGFindependent effect of IGFBP-5, however, is more complicated than its IGF-dependent effects. IGFBP-5 can bind with its putative receptor to enter the cell cytoplasm and can then interact with and regulate the functions of other proteins [89]. Through these protein-protein interactions, IGFBP-5 may regulate the metastatic capacity (Figure $3 b$ ). More than 100 proteins may possibly interact with IGFBP-5, causing it to acquire novel functional properties.

\section{Genetic variation in the IGFBP-5 gene and breast cancer risk}

There is currently limited information regarding IGFBP5 genetic polymorphisms in breast cancer risk. Garner and colleagues, however, recently reported a study that showed a significant association of genetic variation in IGFBP-5 with breast cancer risk in two independent populations of African descents [90]. In their study, researchers focused on the African-American women younger than 40 years of age who have a higher incidence of breast cancer. It was found that the polymorphisms in three exons at the $3^{\prime}$ end of IGFBP5 were associated with the increased risk of breast cancer in African-Americans and Nigerians. The authors proposed that the genetic variant may alter the expression of the IGFBP in the cell, the binding of IGF-1 to the IGFBP, the proteolytic action of the proteases, or the localization of IGFBP5 within the cell. Additional studies will be needed to evaluate the role of IGFBP5 polymorphism in breast cancer risk.

\section{Prognostic significance of IGFBP-5 in breast cancer}

The role of IGFBP-5 in human breast cancer is very complex and is not completely understood. Wood and Yee have shown that IGFBP-5 is not expressed or is only weakly expressed in normal breast epithelium cells in adults [74]. Some studies have also found elevated IGFBP-5 levels in breast cancer tissues [91-93]. Pekonen and colleagues detected IGFBP-5 mRNA in 47 breast cancer tissue specimens by RT-PCR, and found higher levels of IGFBP- 5 content in the tumor specimens than in adjacent normal tissues [91]. IGFBP-5 was also found in breast cancer tissue samples at the protein level using ligand blotting [92]. We also observed that IGFBP-5 protein is overexpressed in breast cancer tissue samples compared with normal tissues, and that the protein is localized to the cytoplasm (unpublished data).

In several independent studies, IGFBP-5 was among the differentially expressed genes that were positively associated 


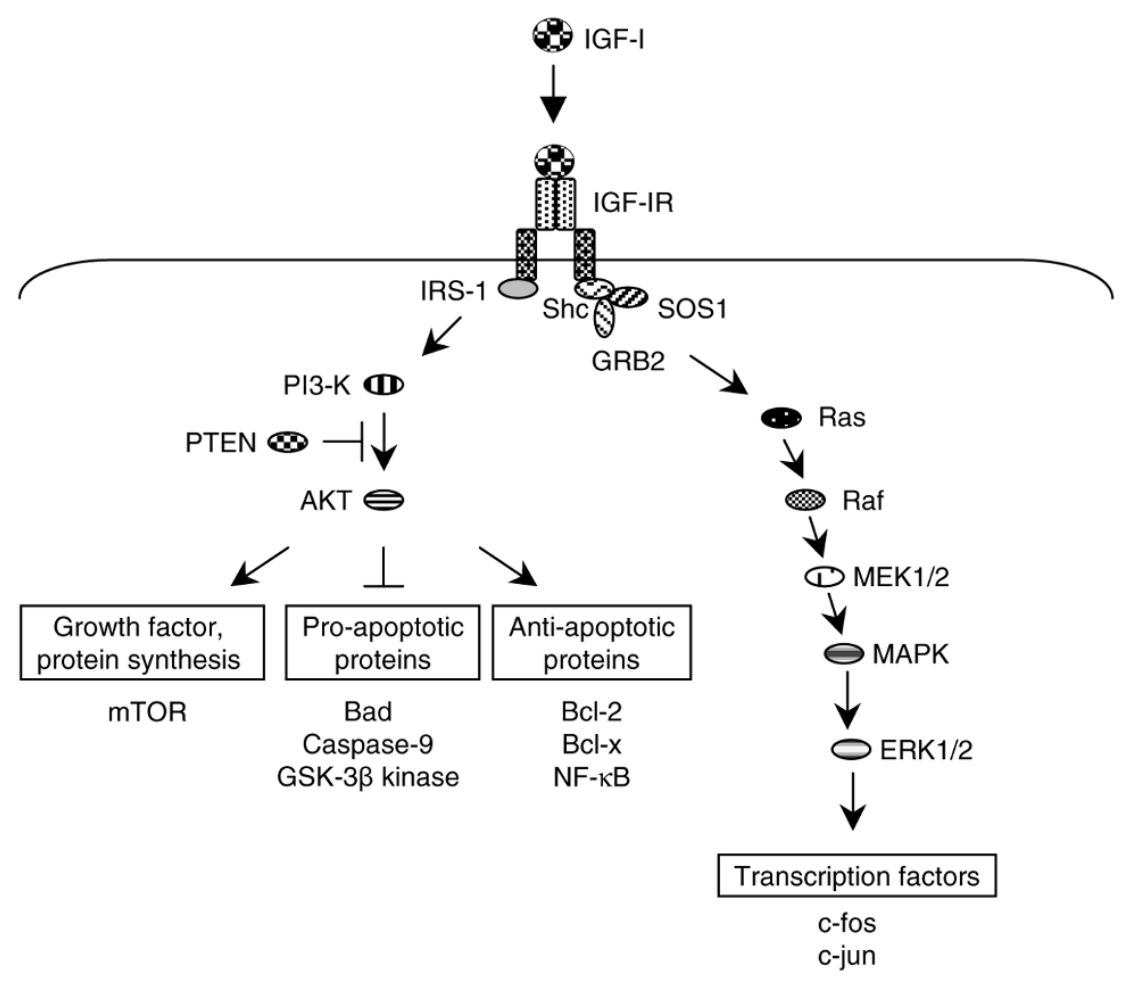

Overview of the insulin-like growth factor-I signaling pathway involved in breast cancer. Insulin-like growth factor I (IGF-I) activates both the Ras/mitogen-activated protein kinase (MAPK) and phosphoinositide 3-kinase (PI3K)/serine-threonine kinase (AKT) pathways, and causes cell growth and proliferation. ERK1/2, extracellular signal-regulated kinase 1/2; GSK, glycogen synthase kinase; IGF-IR, insulin-like growth factor-I receptor; IRS-1, insulin receptor substrate; MEK1/2, mitogen-activated protein/extracellular signal-regulated kinase kinase; mTOR, mammalian target of rapamycin; PTEN, phosphatase and tensin homologue; Shc, GRB2, SOS1, adaptor proteins.

with metastasis $[9,94,95]$. Van 't Veer and colleagues found that IGFBP-5 is one of the 70 signature genes related with a poor prognosis [94]. Hao and colleagues found that IGFBP-5 was overexpressed in lymph node metastases compared with the matched primary cancer tissues [9]. In addition, IGFBP-5 was more frequently overexpressed in $\mathrm{T} 1$ breast carcinoma that has lymph node metastasis compared with $\mathrm{T} 1$ carcinoma with no lymph node metastasis. Furthermore, some studies have shown that the expression of IGFBP-5 is an adverse prognostic factor and correlates with metastasis of breast cancer $[95,96]$.

$\mathrm{Li}$ and colleagues recently evaluated the prognostic significance of IGFBP-5 in breast cancer [14]. They found that the mRNA level of IGFBP-5 correlated positively with the invasion of axillary lymph nodes and the presence of the estrogen receptor (ER). Moreover, an increasing IGFBP-5 mRNA level was associated with a poor outcome for breast cancer patients who had positive lymph nodes and negative ER. Mita and colleagues also investigated the predictive effects of IGFBP-5 on prognosis and endocrine therapy outcome [96]. Their recently published study of a Japanese population indicated that the IGFBP-5 mRNA level was not an independent prognostic factor but, when combined with the IGFBP-4 and ER status, did provide information useful for clinical application. They found that patients who expressed low levels of IGFBP-5 and high levels of IGFBP-4 had a better prognosis only when the breast cancer was ERpositive. They also observed a negative correlation between the level of IGFBP-5 mRNA and HER2 overexpression. These data suggest that IGFBP-5 may play a role in the metastasis of breast carcinomas. Consistent with this notion, IGFBP-5 has been implicated in the progression of other types of cancers, including prostate cancer [97] and thyroid cancers [98]. Table 1 presents the biological roles of IGFBP-5 in other types of cancers.

Apart from the prognostic value of IGFBP-5, other IGFBP proteins as well as IGFBP-5 may affect the response to endocrine therapy in breast cancer. There are studies showing that activation of signal transduction molecules is important for resistance to endocrine therapy [99-102]. The results from our reverse-phase protein lysate microarray assays of 14 breast cancer cell lines support evidence that there are close correlations between the ER status, the IGFBP-2 and IGFBP-5 levels, and the activation of signaling molecules 

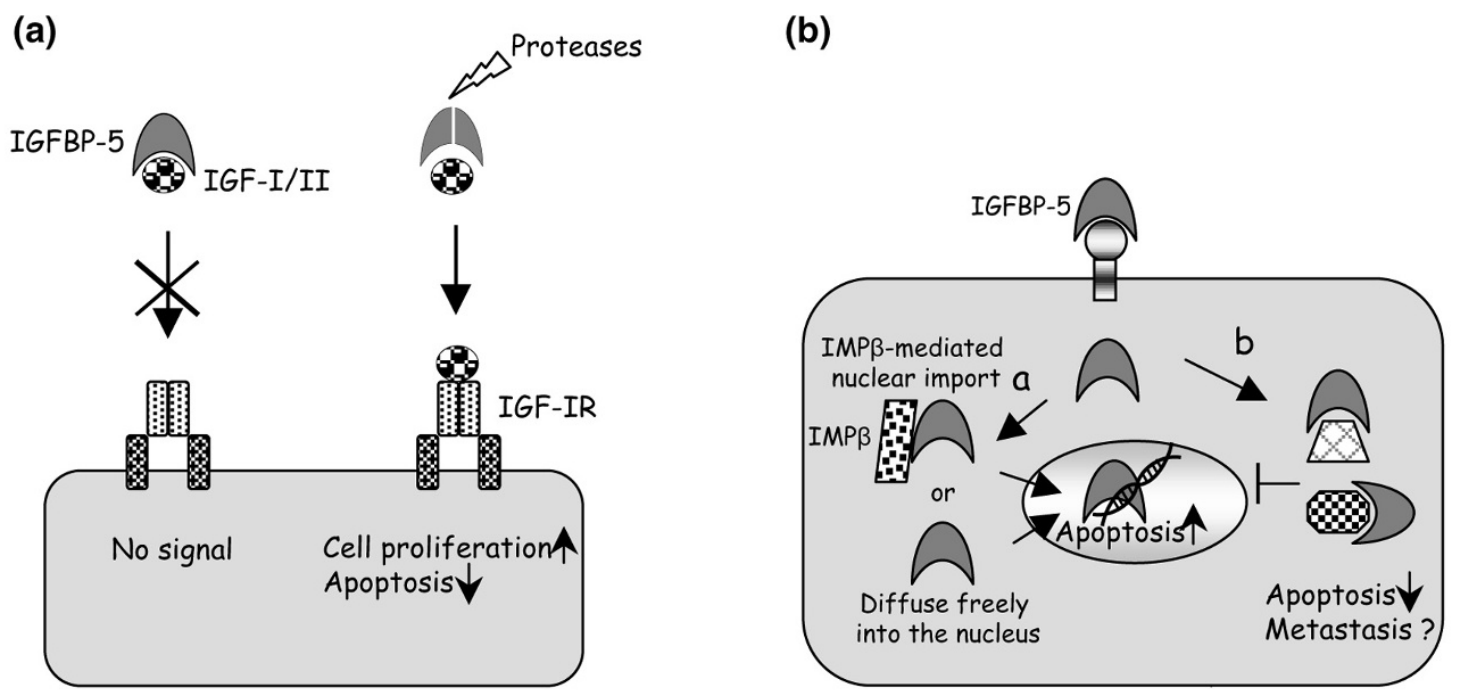

Effects of insulin-like growth factor binding protein 5 in breast cancer. Schematic presentations of insulin-like growth factor (IGF)-dependent and IGF-independent effects of insulin-like growth factor binding protein 5 (IGFBP-5) in breast cancer. (a) Main effects of IGFBP-5 dependent on IGF in breast cancer. IGFBP-5 binds IGF and blocks activation of IGF signaling. If IGFBP-5 is degraded by specific proteases, IGF releases and activates cell proliferation. IGF-IR, insulin-like growth factor-I receptor. (b) IGFBP-5 enters cells by specific receptors or other pathways and determines the cell fate with its cellular localization. Left (arrow a): nuclear import of IGFBP-5 - there are two mechanism through which IGFBP-5 enters the nucleus: importin- $\beta$ (IMP $\beta$ )-mediated or diffusion. Right (arrow b): cytoplasmic accumulation of IGFBP-5 by interaction with other proteins, and stimulation of antiapoptotic effects and metastasis.

[103]. For these reasons, IGFBP-5 has emerged as an important therapeutic target in the treatment of breast cancer.

\section{Is IGFBP-5 a survival factor or a death factor in breast cancer?}

Although the apoptotic potential of IGFBP-5 has been studied extensively, there is still no consensus about whether IGFBP-5 induces apoptosis or promotes cell survival. Perks and colleagues incubated Hs578T breast cancer cells with apoptotic inducers such as ceramide and RGD-containing peptide, and then checked for apoptosis using flow cytometry, the 3-(4,5-dimethylthiazol-2-yl)-2,5-diphenyltetrazolium bromide (MTT) assay, and morphological assessment [104]. They found that exogenously added IGFBP-5 has a protective effect against ceramide-induced apoptosis [104]. This is the first study to show an antiapoptotic effect of IGFBP-5. The same researcher group also investigated the antiapoptotic effect of IGFBP-5 in breast cancer. They used IGF-responsive MCF-7 cells in addition to nonresponsive Hs578T cells and applied nonglycosylated IGFBP-5, glycosylated IGFBP-5, and mutant IGFBP-5 [105]. They found similar results between ceramide and all IGFBP-5 forms in Hs578T cells. In MCF-7 cells, IGFBP-5 might be a contributor to survival effects of IGF in apoptotic stress, which can be blocked by prevention of interaction with its ligand. Recently published clinical observations provide supporting evidence that IGFBP-5 is associated with metastasis and the aggressive tumor phenotype in breast cancer $[9,106]$.
On the other hand, Butt and colleagues have shown that IGFBP-5 prevents the growth of human breast cancer cells in vitro and in vivo [107]. In their study, stable expression of IGFBP-5 inhibited the growth of tumors derived from MDA-MB-231 cells by elevated bax and decreased bcl-2 at the mRNA level. No antiapoptotic effect was identified using exogenously added intact or proteolytic fragments of IGFBP-5 in their study. They suggested that IGFBP-5 inhibitory effects have a novel intracrine mechanism. IGFBP- 5 also sensitizes breast cancer cell lines to the inhibitory effects of TNF $\alpha$ by blocking NF-кB-mediated cell survival signals. Butt and colleagues also found that IGFBP-5 induced and activated both caspase 8 and caspase 9 in the MDA-MB-231 breast cancer cell line [108]. These caspases regulate different apoptotic pathways, including intrinsic and extrinsic pathways. It is possible that functional diversity may arise from its interacting proteins and may depend on its subcellular localization. IGFBP-5 modulates apoptosis through more than one mechanism.

\section{What is the potential effect of IGFBP-5 on cell attachment and migration in breast cancer?}

One of the multifunctional roles of IGFBP-5 is to mediate cell attachment. McCaig and colleagues analyzed the survival signaling mechanism of IGFBP-5 against ceramide-induced cell death [109]. They used specific inhibitors for related survival pathways, such as sphingosine kinase and protein kinase $\mathrm{C}$ in the Hs578T breast cancer cell line. They 
Table 1

Biological roles of insulin-like growth factor binding protein 5 (IGFBP-5) in different types of cancer

\begin{tabular}{|c|c|c|c|c|}
\hline Cancer type & $\begin{array}{l}\text { Source of } \\
\text { tissue or cell line }\end{array}$ & Application of the study or study design & Observed functional effects of IGFBP-5 & Ref. \\
\hline \multirow[t]{5}{*}{ Breast } & T47D & Intracellular trafficking & Nuclear localization of IGFBP-5 & [31] \\
\hline & Hs578T & Analysis of mitogenic effect of IGFBP-5 & $\begin{array}{l}\text { Protective effect against ceramide-induced } \\
\text { apoptosis }\end{array}$ & [104] \\
\hline & Hs578T & Cell attachment applications & $\begin{array}{l}\text { Cell attachment increased by exogenously } \\
\text { added IGFBP-5 }\end{array}$ & [110] \\
\hline & MDA-MB-231 & $\begin{array}{l}\text { Cellular localization and apoptotic role of } \\
\text { IGFBP-5 }\end{array}$ & $\begin{array}{l}\text { IGFBP- } 5 \text { localizes in the nucleus and produces } \\
\text { apoptosis }\end{array}$ & [107] \\
\hline & MDA-MB-231 & Role of IGFBP-5 in the apoptotic pathway & $\begin{array}{l}\text { IGFBP- } 5 \text { induces and activates caspase } 8 \text { and } \\
\text { caspase } 9\end{array}$ & {$[108]$} \\
\hline \multirow[t]{5}{*}{ Neuroblastoma } & B104 & Characterization of IGFBP-5 proteases & A specific serine-metalloprotease for IGFBP-5 & [122] \\
\hline & LAN-5, N1E-115 & Analysis of IGFBP-5 promoter sites & c-Myb and B-Myb enhance IGFBP-5 transcription & {$[45]$} \\
\hline & LAN-5, SY5Y(N) & $\begin{array}{l}\text { Micro and small interfering RNAs directed to } \\
\text { IGFBP-5 mRNA }\end{array}$ & Growth inhibition and more prone to apoptosis & [123] \\
\hline & $\begin{array}{l}\text { Various types } \\
\text { of neuroblastoma } \\
\text { cells }\end{array}$ & Retinoic acid-induced differentiation & Increased expression of IGFBP-5 & {$[47,124]$} \\
\hline & LAN-5, SY $5 Y(N)$ & Silencing IGFBP-5 & Mitochondrial apoptosis & [125] \\
\hline \multirow[t]{5}{*}{ Prostate } & $\begin{array}{l}\text { CWR22, CaP } \\
\text { xenograft }\end{array}$ & Castration and androgen stimulation & Androgen receptor upregulates IGFBP-5 & [126] \\
\hline & $\begin{array}{l}\text { Mouse androgen- } \\
\text { dependent Shionogi } \\
\text { tumor model }\end{array}$ & Castration-induction & Upregulation of IGFBP-5 & [97] \\
\hline & LNCaP & Hormone treatment & No significant effect on IGFBP-5 mRNA level & [127] \\
\hline & PC-3 & $1 \alpha, 25(\mathrm{OH})_{2} \mathrm{D}_{3}$ treatment & $\begin{array}{l}\text { IGFBP- } 5 \text { is primary target gene of the } \\
1 \alpha, 25(\mathrm{OH})_{2} \mathrm{D}_{3}\end{array}$ & [128] \\
\hline & $\begin{array}{l}\text { Bone marrow } \\
\text { stromal cells }\end{array}$ & Androgen suppression treatment & $\begin{array}{l}\text { Increasing IGFBP- } 5 \text { mRNA expression facilitates } \\
\text { prostate cancer progression }\end{array}$ & [129] \\
\hline \multirow[t]{7}{*}{ Osteosarcoma } & $\begin{array}{l}\text { Osteosarcoma U2 } \\
\text { cell line, untrans- } \\
\text { formed normal } \\
\text { human bone cells }\end{array}$ & $\begin{array}{l}\text { Proteolytic degradation of IGFBP-4 and } \\
\text { IGFBP-5 }\end{array}$ & $\begin{array}{l}\text { Proteolytic activity of IGFBP- } 5 \text { can modulate } \\
\text { IGF action in bone }\end{array}$ & [130] \\
\hline & $\begin{array}{l}\text { Rat osteosarcoma } \\
\text { cells }\end{array}$ & $\begin{array}{l}\text { Relationship between growth hormone } \\
\text { receptor and IGFBP-5 }\end{array}$ & $\begin{array}{l}\text { IGFBP- } 5 \text { increases growth hormone receptor } \\
\text { mRNA and growth hormone binding and } \\
\text { potentiates mitogenesis }\end{array}$ & [131] \\
\hline & $\begin{array}{l}\text { OS/50-K8 mouse } \\
\text { osteosarcoma cells }\end{array}$ & Biological activity of IGFBP-5 & $\begin{array}{l}\text { IGFBP- } 5 \text { reduces proliferation and regulates } \\
\text { differentiation }\end{array}$ & [132] \\
\hline & $\begin{array}{l}\text { U2 human } \\
\text { osteosarcoma cells }\end{array}$ & Examination of IGFBP-5 proteases & $\begin{array}{l}\text { ADAM- } 9 \text { cleaved IGFBP- } 5 \text { specifically and is } \\
\text { produced by osteoblast cell types }\end{array}$ & [133] \\
\hline & Bone cells & Silencing of IGFBP-5 & $\begin{array}{l}\text { Knockdown of IGFBP- } 5 \text { induced DNA synthesis } \\
\text { and reduced differentiation }\end{array}$ & [134] \\
\hline & $\begin{array}{l}\text { U2 human } \\
\text { osteosarcoma cells }\end{array}$ & Detection of IGFBP-5 interacting proteins & A novel IGFBP-5 interacting protein (IGFBP5-IP) & {$[135]$} \\
\hline & $\begin{array}{l}\text { LSaOS human } \\
\text { osteosarcoma } \\
\text { cell line }\end{array}$ & IGFBP-5 regulations in bone & $\begin{array}{l}\text { Four-and-a-half LIM protein } 2 \text { and ADAM- } 9 \text { are } \\
\text { major modulators of IGFBP- } 5 \text { actions }\end{array}$ & [136] \\
\hline Ovarian & $\begin{array}{l}\text { Human ovarian } \\
\text { carcinoma lines }\end{array}$ & IGFBP levels & $\begin{array}{l}\text { Expression of IGFBP- } 5 \text { appears as a rather } \\
\text { rare event }\end{array}$ & [137] \\
\hline
\end{tabular}


Table 1

\begin{tabular}{|c|c|c|c|c|}
\hline Cancer type & $\begin{array}{l}\text { Source of } \\
\text { tissue or cell line }\end{array}$ & Application of the study or study design & Observed functional effects of IGFBP-5 & Ref. \\
\hline \multirow[t]{2}{*}{ Ovarian } & $\begin{array}{l}\text { Various types of } \\
\text { ovarian cancers }\end{array}$ & Examine IGFBP-2 and IGFBP-5 levels & $\begin{array}{l}\text { Overexpression of IGFBP-5 in high-grade } \\
\text { ovarian carcinoma }\end{array}$ & [138] \\
\hline & $\begin{array}{l}\text { Ovarian cancer } \\
\text { patients }\end{array}$ & $\begin{array}{l}\text { Evaluate predictive value of IGFBPs in } \\
\text { aromatase inhibitor letrozole }\end{array}$ & $\begin{array}{l}\text { IGFBP- } 5 \text { is a predictive marker for endocrine } \\
\text { therapy }\end{array}$ & [139] \\
\hline \multirow[t]{2}{*}{ Cervical } & $\begin{array}{l}\text { HPV(-) C33A, } \\
\text { HPV(+) CaSki cells }\end{array}$ & Retinoic acid treatment & $\begin{array}{l}\text { IGFBP- } 5 \text { overexpression determines retinoic } \\
\text { acid effects in human papilloma virus(-) cells }\end{array}$ & [48] \\
\hline & $\begin{array}{l}\text { Squamous cell } \\
\text { carcinomas }\end{array}$ & Cervical carcinogenesis & Downregulation of IGFBP-5 & [140] \\
\hline \multirow[t]{2}{*}{ Colon } & LoVo cells & NS398 treatment & IGFBP-5 might be a target of NS398 & [141] \\
\hline & $\begin{array}{l}\text { Colon epithelial } \\
\text { cells }\end{array}$ & Leptin treatment & Downregulation of IGFBP-5 by leptin treatment & [142] \\
\hline \multirow[t]{2}{*}{ Renal } & $\begin{array}{l}\text { Oncocytomas, } \\
\text { clear cell and } \\
\text { papillary renal } \\
\text { cell carcinoma }\end{array}$ & Changes of IGF/IGFBPs & $\begin{array}{l}\text { Downregulation of IGFBP- } 5 \text { in papillary } \\
\text { renal cell carcinoma and oncocytomas }\end{array}$ & [143] \\
\hline & $\begin{array}{l}\text { Clear cell renal } \\
\text { cell carcinoma }\end{array}$ & Analysis of IGF-axis components & Downregulation of IGFBP-5 & [144] \\
\hline Lung & $\begin{array}{l}\text { Lung squamous } \\
\text { cell carcinomas, } \\
\text { and normal } \\
\text { bronchial epithelial } \\
\text { tissues }\end{array}$ & Identification of differentially expressed genes & Overexpression of IGFBP-5 & [145] \\
\hline Gastric & $\begin{array}{l}\text { A panel of human } \\
\text { gastric cancer cell } \\
\text { lines, and normal } \\
\text { and tumor tissues }\end{array}$ & Detect IGFs and IGFBP levels & One-half of the tumor cells express IGFBP-5 & [146] \\
\hline Thyroid & $\begin{array}{l}\text { Various types of } \\
\text { thyroid tissues }\end{array}$ & IGFBP-5 levels & Overexpression of IGFBP-5 in papillary carcinoma & [98] \\
\hline Pancreas & $\begin{array}{l}\text { Pancreatic ductal } \\
\text { adenocarcinoma }\end{array}$ & Differential expression of genes & Overexpression of IGFBP-5 & [147] \\
\hline
\end{tabular}

$1 \alpha, 25(\mathrm{OH}){ }_{2} \mathrm{D}_{3}=1 \alpha, 25$-dihydroxyvitamin $\mathrm{D}_{3} ; \mathrm{IGF}=$ insulin-like growth factor; IGFBP = insulin-like growth factor binding protein.

observed that IGFBP-5 promotes cell attachment and survival and is affected by signaling pathways. McCaig and colleagues also used different ECM components - such as laminin, collagen type IV, and fibronectin - to investigate the role of IGFBPs in cell attachment in the Hs578T breast cancer cell line [110]. They found that cell attachment to a general ECM such as laminin and collagen type IV was increased by exogenously added IGFBP-5, whereas attachment to fibronectin was decreased by IGFBP-5. They suggested that the presence of fibronectin in matrix components determines cell survival and depends on intrinsic action of IGFBP-5.

One of the ECM proteins, vitronectin, is critical for some of the IGF-I-related actions, including DNA synthesis, IGF-IR autophosphorylation, and cell migration. Kricker and colleagues investigated potential effects of IGF-I-vitronectin interaction and the functional roles of IGFBPs [71]. They found that IGFBP-5 enhanced binding of IGF-I to vitronectin. They also found that the IGF-I-IGFBP-5-vitronectin complex increases cell migration in MCF7 cells. Their study also showed an IGFI-dependent migration effect of IGFBP-5. Kricker and colleagues' findings are consistent with the data from studies using human breast tissue samples, and support the notion that IGFBP-5 plays a role in cell migration and invasion of breast cancer.

\section{Crosstalk between IGFBP-5 and estrogen receptors in breast cancer}

Estrogen and IGFs are major growth regulatory hormones with similar signal transduction pathways (ligand-receptor interaction followed by downstream cascade). They have a synergistic effect on cell proliferation in the MCF-7 breast cancer cell line. The crosstalks between these two pathways 
have been identified and reviewed [111,112]; both systems and their interactions are related to increased resistance to hormone therapy and cancer recurrence. Lee and colleagues have shown that transcriptional activation of the ER is controlled by IGF-I in breast cancer cells [113]. Estradiol induced expression of IRS-1, which activates downstream signaling of IGF-I and potentiates its cell proliferative ability. Antiestrogens may downregulate IRS-1, which could be one of the possible mechanisms involved in the development of the antiestrogen response [114]. IGF-IR mitogenic and nonmitogenic functions may depend on the ER status in the breast cancer cell line. In the ER-negative MDA-MB-231 breast cancer cell line, IGF-IR may regulate migration and the adhesion abilities of these cells; whereas in ER-positive MCF-7 breast cancer cells, IGF-IR can modulate mitogenic stimulation [115]. The interactions and communications between the IGF axis and the ER pathway in breast cancer are therefore important in the development of breast cancer.

There is also evidence that estrogen regulates IGFBP-5 expression in breast cancers. In vitro studies have shown that growth inhibition of MCF-7 human breast cancer cells induced by the antiestrogen $\mathrm{ICl} 182,780$ is associated with increased transcription of the IGFBP-5 gene and increased IGFBP-5 protein accumulation in the conditioned medium. Similar results have been reported by other groups $[116,117]$. These data suggest that IGFBP-5 plays a role in modulating the proliferation of breast cancers by estrogens and antiestrogens. On the other hand, antiestrogen $\mathrm{ICl}$ 164384 has also been shown to transiently decrease the steady-state mRNA level of IGFBP-5 in T-47D cells [118]. Both estrogens and antiestrogens (ICl 182,780 and tamoxifen) could enhance the expression of IGFBP-5 in the MCF-7 breast cancer cell line [119].

In our own studies, we used protein lysate array technology to analyze the association between IGFBP-5 and ER status and some signaling proteins, cell cycle proteins, and apoptotic proteins and their phosphorylation profiles in 14 breast cancer cell lines. We found a positive correlation between overexpression of IGFBP-5 and the presence of ER and also downstream signaling pathways in breast cell lines [103]. Similar findings have been observed in breast cancer tissues [120]. The mRNA level of IGFBP-5 was greater in ERpositive cancer tissues than in ER-negative tissues [92]. The relationship between signal transduction pathways and ER status was reviewed by Normanno and colleagues [121]. In the near future, IGFBP-5 will probably be an important predictive marker for resistance and responses during antiestrogen therapy for breast cancer. Some microarray data support the idea that the IGFBP-5 expression level determines tamoxifen responsiveness [99].

\section{Conclusions}

IGFBP-5 is one of the critical members of the IGF system for both normal cell physiology and tumorigenesis. IGFBP-5 function is affected by many conditions: presence of the ligand, interacting proteins, proteolytic degradation, posttranslational modifications, transcriptional regulation, and cellular localization. Research in the future should result in new knowledge regarding novel IGFBP-5-interacting proteins, new tissue-specific proteases, different functional roles of post-translational modifications on IGFBP-5, transcriptional regulator genes, and the logic and mechanisms of cellular trafficking of IGFBP-5 in different types of tumors. When such future studies are completed and a consensus is reached regarding the experimental data and related clinical findings, this protein may well prove to play a role as one of the most important targets in breast cancer therapeutics.

\section{Competing interests}

The authors declare that they have no competing interests.

\section{Acknowledgement}

The authors would like to thank Michael Worley in the Department of Scientific Publication at the MD Anderson Cancer Center for editing the manuscript. This work is partly supported by a grant (BC044966 to WZ) from the Department of Defense Breast Cancer Research Program of the Office of the Congressionally Directed Medical Research Programs.

\section{References}

1. Firth SM, Baxter RC: Cellular actions of the insulin-like growth factor binding proteins. Endocr Rev 2002, 23:824-854.

2. Beattie J, Allan GJ, Lochrie JD, Flint D: Insulin-like growth factor-binding protein-5 (IGFBP-5): a critical member of the IGF axis. Biochem J 2006, 395:1-19.

3. Hwa V, Oh Y, Rosenfeld RG: The insulin-like growth factorbinding protein (IGFBP) superfamily. Endocr Rev 1999, 20: 761-787.

4. Jones $\mathrm{Jl}$, Clemmons DR: Insulin-like growth factors and their binding proteins: biological actions. Endocr Rev 1995, 16:3-34.

5. Valentinis $B$, Baserga R: IGF-I receptor signalling in transformation and differentiation. Mol Pathol 2001, 54:133-137.

6. Kim JJ, Accili D: Signalling through IGF-I and insulin receptors: where is the specificity? Growth Horm IGF Res 2002, 12:84-90.

7. Renehan $A G$, Harvie $M$, Howell $A$ : Insulin-like growth factor (IGF)-I, IGF binding protein-3, and breast cancer risk: eight years on. Endocr Relat Cancer 2006, 13:273-278.

8. Sachdev D, Yee D: The IGF system and breast cancer. Endocr Relat Cancer 2001, 8:197-209.

9. Hao X, Sun B, Hu L, Lahdesmaki H, Dunmire V, Feng Y, Zhang SW, Wang H, Wu C, Wang H, Fuller GN, Symmans WF, Shmulevich I, Zhang W. Differential gene and protein expression in primary breast malignancies and their lymph node metastases as revealed by combined cDNA microarray and tissue microarray analysis. Cancer 2004, 100:1110-1122.

10. Morgan DO, Edman JC, Standring DN, Fried VA, Smith MC, Roth RA, Rutter WJ: Insulin-like growth factor II receptor as a multifunctional binding protein. Nature 1987, 329:301-307.

11. Mohan S, Baylink DJ: IGF-binding proteins are multifunctional and act via IGF-dependent and -independent mechanisms. $J$ Endocrinol 2002, 175:19-31.

12. Hoeflich A, Reisinger R, Lahm H, Kiess W, Blum WF, Kolb HJ, Weber MM, Wolf E: Insulin-like growth factor-binding protein 2 in tumorigenesis: protector or promoter? Cancer Res 2001, 61:8601-8610.

13. Renehan AG, Zwahlen M, Minder C, O'Dwyer ST, Shalet SM, Egger M: Insulin-like growth factor (IGF)-I, IGF binding protein-3, and cancer risk: systematic review and metaregression analysis. Lancet 2004, 363:1346-1353.

14. Li X, Cao X, Li X, Zhang W, Feng Y: Expression level of insulinlike growth factor binding protein 5 mRNA is a prognostic factor for breast cancer. Cancer Sci 2007, 98:1592-1596.

15. Zhu $X$, Ling N, Shimasaki S: Cloning of the rat insulin-like growth factor binding protein-5 gene and DNA sequence 
analysis of its promoter region. Biochem Biophys Res Commun 1993, 190:1045-1052.

16. Allander SV, Larsson C, Ehrenborg E, Suwanichkul A, Weber G, Morris SL, Bajalica S, Kiefer MC, Luthman H, Powell DR: Characterization of the chromosomal gene and promoter for human insulin-like growth factor binding protein-5. J Biol Chem 1994, 269:10891-10898.

17. Ehrenborg E, Larsson C, Stern I, Janson M, Powell DR, Luthman $\mathrm{H}$ : Contiguous localization of the genes encoding human insulin-like growth factor binding proteins 1 (IGBP1) and 3 (IGBP3) on chromosome 7. Genomics 1992, 12:497-502.

18. Kalus W, Zweckstetter M, Renner C, Sanchez Y, Georgescu J, Grol M, Demuth D, Schumacher R, Dony C, Lang K, Holak TA: Structure of the IGF-binding domain of the insulin-like growth factor-binding protein-5 (IGFBP-5): implications for IGF and IGF-I receptor interactions. EMBO J 1998, 17:6558-6572.

19. Imai Y, Moralez A, Andag U, Clarke JB, Busby WH Jr, Clemmons DR: Substitutions for hydrophobic amino acids in the N-terminal domains of IGFBP- 3 and -5 markedly reduce IGF-I binding and alter their biologic actions. J Biol Chem 2000, 275:1818818194.

20. Conover CA, Kiefer MC: Regulation and biological effect of endogenous insulin-like growth factor binding protein-5 in human osteoblastic cells. J Clin Endocrinol Metab 1993, 76: 1153-1159.

21. Ständker L, Wobst $P$, Mark $S$, Forssmann WG: Isolation and characterization of circulating 13-kDa C-terminal fragments of human insulin-like growth factor binding protein-5. FEBS Lett 1998, 441:281-286.

22. Coverley JA, Baxter RC: Phosphorylation of insulin-like growth factor binding proteins. Mol Cell Endocrinol 1997, 128:1-5.

23. Clemmons DR, Busby W, Clarke JB, Parker A, Duan C, Nam TJ: Modifications of insulin-like growth factor binding proteins and their role in controlling IGF actions. Endocr $J$ 1998, 45 (Suppl):S1-S8.

24. Bunn RC, Fowlkes JL: Insulin-like growth factor binding protein proteolysis. Trends Endocrinol Metab 2003, 14:176-181.

25. Busby WH Jr, Nam TJ, Moralez A, Smith C, Jennings M, Clemmons DR: The complement component $\mathrm{C} 1 \mathrm{~s}$ is the protease that accounts for cleavage of insulin-like growth factorbinding protein-5 in fibroblast medium. J Biol Chem 2000, 275:37638-37644.

26. Thrailkill KM, Quarles LD, Nagase H, Suzuki K, Serra DM, Fowlkes $\mathrm{JL}$ : Characterization of insulin-like growth factor-binding protein 5-degrading proteases produced throughout murine osteoblast differentiation. Endocrinology 1995, 136:3527-3533.

27. Loechel F, Fox JW, Murphy G, Albrechtsen R, Wewer UM: ADAM 12-S cleaves IGFBP-3 and IGFBP-5 and is inhibited by TIMP-3. Biochem Biophys Res Commun 2000, 278:511-515.

28. Overgaard MT, Boldt HB, Laursen LS, Sottrup-Jensen L, Conover CA, Oxvig C: Pregnancy-associated plasma protein-A2 (PAPP-A2), a novel insulin-like growth factor-binding protein-5 proteinase. J Biol Chem 2001, 276:21849-21853.

29. Conover CA, Perry JE, Tindall DJ: Endogenous cathepsin Dmediated hydrolysis of insulin-like growth factor-binding proteins in cultured human prostatic carcinoma cells. J Clin Endocrinol Metab 1995, 80:987-993.

30. Radulescu RT: Nuclear localization signal in insulin-like growth factor-binding protein type 3 [abstract]. Trends Biochem Sci 1994, 19:278.

31. Schedlich LJ, Young TF, Firth SM, Baxter RC: Insulin-like growth factor-binding protein (IGFBP)-3 and IGFBP-5 share a common nuclear transport pathway in T47D human breast carcinoma cells. J Biol Chem 1998, 273:18347-18352.

32. Schedlich LJ, Le Page SL, Firth SM, Briggs LJ, Jans DA, Baxter RC: Nuclear import of insulin-like growth factor-binding protein-3 and -5 is mediated by the importin beta subunit. $J$ Biol Chem 2000, 275:23462-23470.

33. Jurgeit $A$, Berlato $C$, Obrist $P$, Ploner $C$, Massoner $P$, Schmölzer J, Haffner MC, Klocker H, Huber LA, Geley S, Doppler W: Insulinlike growth factor-binding protein-5 enters vesicular structures but not the nucleus. Traffic 2007, 8:1815-1828.

34. Abrass CK, Berfield AK, Andress DL: Heparin binding domain of insulin-like growth factor binding protein-5 stimulates mesangial cell migration. Am J Physiol 1997, 273:F899-F906.

35. Allan GJ, Tonner E, Szymanowska M, Shand JH, Kelly SM, Phillips K, Clegg RA, Gow IF, Beattie J, Flint DJ: Cumulative mutagene- sis of the basic residues in the 201-218 region of insulin-like growth factor (IGF)-binding protein-5 results in progressive loss of both IGF-I binding and inhibition of IGF-I biological action. Endocrinology 2006, 147:338-349.

36. Shemer J, Yaron A, Werner H, Shao ZM, Sheikh MS, Fontana JA, LeRoith D, Roberts CT Jr: Regulation of insulin-like growth factor (IGF) binding protein-5 in the T47D human breast carcinoma cell line by IGF-I and retinoic acid. J Clin Endocrinol Metab 1993, 77:1246-1250.

37. Kou K, Jenkins NA, Gilbert DJ, Copeland NG, Rotwein P: Organization, expression, and chromosomal location of the mouse insulin-like growth factor binding protein 5 gene. Genomics 1994, 20:412-418.

38. Kou K, Mittanck DW, Fu C, Rotwein P: Structure and function of the mouse insulin-like growth factor binding protein 5 gene promoter. DNA Cell Biol 1995, 14:241-249.

39. Duan C, Clemmons DR: Transcription factor AP-2 regulates human insulin-like growth factor binding protein-5 gene expression. J Biol Chem 1995, 270:24844-24851.

40. McCarthy TL, Casinghino S, Mittanck DW, Ji CH, Centrella M, Rotwein P: Promoter-dependent and -independent activation of insulin-like growth factor binding protein-5 gene expression by prostaglandin $E_{2}$ in primary rat osteoblasts. $J$ Biol Chem 1996, 271:6666-6671.

41. Gabbitas B, Pash JM, Delany AM, Canalis E: Cortisol inhibits the synthesis of insulin-like growth factor-binding protein-5 in bone cell cultures by transcriptional mechanisms. J Biol Chem 1996, 271:9033-9038.

42. Ji C, Chen $\mathrm{Y}$, Centrella M, McCarthy TL: Activation of the insulin-like growth factor-binding protein-5 promoter in osteoblasts by cooperative E box, CCAAT enhancer-binding protein, and nuclear factor-1 deoxyribonucleic acid-binding sequences. Endocrinology 1999, 140:4564-4572.

43. Yeh LC, Adamo ML, Duan C, Lee JC: Osteogenic protein-1 regulates insulin-like growth factor-I (IGF-I), IGF-II, and IGFbinding protein-5 (IGFBP-5) gene expression in fetal rat calvaria cells by different mechanisms. J Cell Physiol 1998, 175:78-88.

44. Yeh LC, Lee JC: Identification of an osteogenic protein-1 (bone morphogenetic protein-7)-responsive element in the promoter of the rat insulin-like growth factor-binding protein5 gene. Endocrinology 2000, 141:3278-3286.

45. Tanno B, Negroni A, Vitali R, Pirozzoli MC, Cesi V, Mancini C, Calabretta B, Raschellà G: Expression of insulin-like growth factor-binding protein $\mathbf{5}$ in neuroblastoma cells is regulated at the transcriptional level by $\mathrm{c}-\mathrm{Myb}$ and $\mathrm{B}-\mathrm{Myb}$ via direct and indirect mechanisms. J Biol Chem 2002, 277:23172-23180.

46. Aranda $A$, Pascual $A$ : Nuclear hormone receptors and gene expression. Physiol Rev 2001, 81:1269-1304.

47. Cesi V, Giuffrida ML, Vitali R, Tanno B, Mancini C, Calabretta B, Raschellà G: C/EBP alpha and beta mimic retinoic acid activation of IGFBP-5 in neuroblastoma cells by a mechanism independent from binding to their site. Exp Cell Res 2005, 305: 179-189.

48. Higo H, Duan C, Clemmons DR, Herman B: Retinoic acid inhibits cell growth in HPV negative cervical carcinoma cells by induction of insulin-like growth factor binding protein-5 (IGFBP-5) secretion. Biochem Biophys Res Commun 1997, 239:706-709.

49. Dong $Y$, Canalis $E$ : Insulin-like growth factor (IGF) I and retinoic acid induce the synthesis of IGF-binding protein $\mathbf{5}$ in rat osteoblastic cells. Endocrinology 1995, 136:2000-2006.

50. Hwa V, Oh Y, Rosenfeld RG: Insulin-like growth factor binding protein- 3 and -5 are regulated by transforming growth factorbeta and retinoic acid in the human prostate adenocarcinoma cell line PC-3. Endocrine 1997, 6:235-242.

51. Colston KW, Berger U, Coombes RC: Possible role for vitamin D in controlling breast cancer cell proliferation. Lancet 1989, 1:188-191.

52. Darwish HM, DeLuca HF: Recent advances in the molecular biology of vitamin D action. Prog Nucleic Acid Res Mol Biol 1996, 53:321-344.

53. Rozen F, Yang XF, Huynh H, Pollak M: Antiproliferative action of vitamin D-related compounds and insulin-like growth factorbinding protein $\mathbf{5}$ accumulation. J Nat/ Cancer Inst 1997, 89: 652-656.

54. Twigg SM, Baxter RC: Insulin-like growth factor (IGF)-binding 
protein $\mathbf{5}$ forms an alternative ternary complex with IGFs and the acid-labile subunit. J Biol Chem 1998, 273:6074-6079.

55. Twigg SM, Kiefer MC, Zapf J, Baxter RC: Insulin-like growth factor-binding protein-5 complexes with the acid-labile subunit. J Biol Chem 1998, 273:28791-28798.

56. Arai T, Arai A, Busby WH Jr, Clemmons DR: Glycosaminoglycans inhibit degradation of insulin-like growth factor-binding protein-5. Endocrinology 1994, 135:2358-2363.

57. Arai T, Parker A, Busby W Jr, Clemmons DR: Heparin, heparan sulfate, and dermatan sulfate regulate formation of the insulin-like growth factor-I and insulin-like growth factorbinding protein complexes. J Biol Chem 1994, 269:2038820393.

58. Beattie J, Phillips K, Shand JH, Szymanowska M, Flint DJ, Allan GJ: Molecular recognition characteristics in the insulin-like growth factor (IGF)-insulin-like growth factor binding protein-3/5 (IGFBP-3/5) heparin axis. J Mol Endocrinol 2005, 34:163-175.

59. Xu O, Yan B, Li S, Duan C: Fibronectin binds insulin-like growth factor-binding protein 5 and abolishes its liganddependent action on cell migration. J Biol Chem 2004, 279: 4269-4277.

60. Nam TJ, Busby WH, Rees C, Clemmons DR: Thrombospondin and osteopontin bind to insulin-like growth factor (IGF)binding protein-5 leading to an alteration in IGF-I-stimulated cell growth. Endocrinology 2000, 141:1100-1106.

61. Amaar YG, Thompson GR, Linkhart TA, Chen ST, Baylink DJ, Mohan S: Insulin-like growth factor-binding protein-5 (IGFBP5) interacts with a four and a half LIM protein 2 (FHL2). J Biol Chem 2002, 277:12053-12060.

62. Nam TJ, Busby W, Clemmons DR: Insulin-like growth factorbinding protein-5 binds to plasminogen activator inhibitor-l. Endocrinology 1997, 138:2972-2978.

63. Nam T, Moralez A, Clemmons D: Vitronectin binding to IGF binding protein-5 (IGFBP-5) alters IGFBP-5 modulation of IGF-I actions. Endocrinology 2002, 143:30-36.

64. Hyde C, Hollier B, Anderson A, Harkin D, Upton Z: Insulin-like growth factors (IGF) and IGF-binding proteins bound to vitronectin enhance keratinocyte protein synthesis and migration. J Invest Dermato/ 2004, 122:1198-1206.

65. Amaar YG, Baylink DJ, Mohan S: Ras-association domain family 1 protein, RASSF1C, is an IGFBP-5 binding partner and a potential regulator of osteoblast cell proliferation. $J$ Bone Miner Res 2005, 20:1430-1439.

66. Jones Jl, Gockerman A, Busby WH Jr, Camacho-Hubner C, Clemmons DR: Extracellular matrix contains insulin-like growth factor binding protein-5: potentiation of the effects of IGF-I. J Cell Biol 1993, 121:679-687.

67. Bramani S, Song H, Beattie J, Tonner E, Flint DJ, Allan GJ: Amino acids within the extracellular matrix (ECM) binding region (201-218) of rat insulin-like growth factor binding protein (IGFBP)-5 are important determinants in binding IGF-I. $J \mathrm{Mol}$ Endocrinol 1999, 23:117-123.

68. Song H, Beattie J, Campbell IW, Allan GJ: Overlap of IGF- and heparin-binding sites in rat IGF-binding protein-5. J Mol Endocrinol 2000, 24:43-51.

69. Twigg SM, Kiefer MC, Zapf J, Baxter RC: A central domain binding site in insulin-like growth factor binding protein-5 for the acid-labile subunit. Endocrinology 2000, 141:454-457.

70. Moralez AM, Maile LA, Clarke J, Busby WH Jr, Clemmons DR: Insulin-like growth factor binding protein-5 (IGFBP-5) interacts with thrombospondin-1 to induce negative regulatory effects on IGF-I actions. J Cell Physio/ 2005, 203:328-334.

71. Kricker JA, Towne CL, Firth SM, Herington AC, Upton Z: Structural and functional evidence for the interaction of insulin-like growth factors (IGFs) and IGF binding proteins with vitronectin. Endocrinology 2003, 144:2807-2815.

72. Hadsell DL, Bonnette SG, Lee AV: Genetic manipulation of the IGF-I axis to regulate mammary gland development and function. J Dairy Sci 2002, 85:365-377.

73. Neuenschwander S, Schwartz A, Wood TL, Roberts CT Jr, Hennighausen L, LeRoith $\mathrm{D}$ : Involution of the lactating mammary gland is inhibited by the IGF system in a transgenic mouse model. J Clin Invest 1996, 97:2225-2232.

74. Wood TL, Yee D: IGFs and IGFBPs in the normal mammary gland and in breast cancer. J Mammary Gland Biol Neoplasia 2000, 5:1-5.
75. Flint DJ, Tonner E, Allan GJ: Insulin-like growth factor binding proteins: IGF-dependent and -independent effects in the mammary gland. J Mammary Gland Biol Neoplasia 2000, 5:6573.

76. Marshman E, Green KA, Flint DJ, White A, Streuli CH, Westwood $\mathrm{M}$ : Insulin-like growth factor binding protein $\mathbf{5}$ and apoptosis in mammary epithelial cells. J Cell Sci 2003, 116:675-682.

77. Tonner E, Quarrie L, Travers M, Barber M, Logan A, Wilde C, Flint D: Does an IGF-binding protein (IGFBP) present in involuting rat mammary gland regulate apoptosis? Prog Growth Factor Res 1995, 6:409-414.

78. Tonner E, Barber MC, Travers MT, Logan A, Flint DJ: Hormonal control of insulin-like growth factor-binding protein-5 production in the involuting mammary gland of the rat. Endocrinology 1997, 138:5101-5107.

79. Tonner E, Barber MC, Allan GJ, Beattie J, Webster J, Whitelaw $\mathrm{CB}$, Flint DJ: Insulin-like growth factor binding protein-5 (IGFBP-5) induces premature cell death in the mammary glands of transgenic mice. Development 2002, 129:4547-4557.

80. Sutherland KD, Lindeman GJ, Visvader JE: The molecular culprits underlying precocious mammary gland involution. J Mammary Gland Biol Neoplasia 2007, 12:15-23.

81. Baxter FO, Neoh K, Tevendale MC: The beginning of the end: death signaling in early involution. J Mammary Gland Biol Neoplasia 2007, 12:3-13.

82. Marshman $\mathrm{E}$, Streuli $\mathrm{CH}$ : Insulin-like growth factors and insulin-like growth factor binding proteins in mammary gland function. Breast Cancer Res 2002, 4:231-239.

83. Chapman RS, Lourenco PC, Tonner E, Flint DJ, Selbert S, Takeda K, Akira S, Clarke AR, Watson CJ: Suppression of epithelial apoptosis and delayed mammary gland involution in mice with a conditional knockout of Stat3. Genes Dev 1999, 13: 2604-2616.

84. Lochrie JD, Phillips K, Tonner E, Flint DJ, Allan GJ, Price NC Beattie J: Insulin-like growth factor binding protein (IGFBP)-5 is upregulated during both differentiation and apoptosis in primary cultures of mouse mammary epithelial cells. $J$ Cell Physiol 2006, 207:471-479.

85. Ning Y, Hoang B, Schuller AG, Cominski TP, Hsu MS, Wood TL Pintar JE: Delayed mammary gland involution in mice with mutation of the insulin-like growth factor binding protein 5 gene. Endocrinology 2007, 148:2138-2147.

86. Sivaraman VS, Wang H, Nuovo GJ, Malbon CC: Hyperexpression of mitogen-activated protein kinase in human breast cancer. J Clin Invest 1997, 99:1478-1483.

87. Esteva FJ, Sahin AA, Smith TL, Yang Y, Pusztai L, Nahta R, Buchholz TA, Buzdar AU, Hortobagyi GN, Bacus SS: Prognostic significance of phosphorylated P38 mitogen-activated protein kinase and HER-2 expression in lymph node-positive breast carcinoma. Cancer 2004, 100:499-506.

88. Wu Y, Mohamed H, Chillar R, Ali I, Clayton S, Slamon D, Vadgama JV: Clinical significance of Akt and HER2/neu overexpression in African American and Latina women with breast cancer: a retrospective cohort study. Breast Cancer Res 2008, 10:R3.

89. Leal SM, Huang SS, Huang JS: Interactions of high affinity insulin-like growth factor-binding proteins with the type V transforming growth factor-beta receptor in mink lung epithelial cells. J Biol Chem 1999, 274:6711-6717.

90. Garner CP, Ding YC, John EM, Ingles SA, Olopade OI, Huo D, Adebamowo C Ogundiran T, Neuhausen SL: Genetic variation in IGFBP2 and IGFBP5 is associated with breast cancer in populations of African descent. Hum Genet 2008, 123:247-255.

91. Pekonen F, Nyman T, Ilvesmäki V, Partanen S: Insulin-like growth factor binding proteins in human breast cancer tissue. Cancer Res 1992, 52:5204-5207.

92. McGuire SE, Hilsenbeck SG, Figueroa JA, Jackson JG, Yee D: Detection of insulin-like growth factor binding proteins (IGFBPs) by ligand blotting in breast cancer tissues. Cancer Lett 1994, 77:25-32.

93. Huynh $\mathrm{H}$ : In vivo regulation of the insulin-like growth factor system of mitogens by human chorionic gonadotropin. Int J Oncol 1998, 13:571-575.

94. Van 't Veer LJ, Dai H, van de Vijver MJ, He YD, Hart AA, Mao M, Peterse HL, van der Kooy K, Marton MJ, Witteveen AT, Schreiber GJ, Kerkhoven RM, Roberts C, Linsley PS, Bernards R, Friend $\mathrm{SH}$ : Gene expression profiling predicts clinical outcome of 
breast cancer. Nature 2002, 415:530-536.

95. Nishidate T, Katagiri T, Lin ML, Mano Y, Miki Y, Kasumi F, Yoshimoto M, Tsunoda T, Hirata K, Nakamura Y: Genome-wide gene expression profiles of breast cancer cells purified with laser microbeam microdissection: identification of genes associated with progression and metastasis. Int J Oncol 2004, 25: 797-819.

96. Mita K, Zhang Z, Ando Y, Toyama T, Hamaguchi M, Kobayashi S, Hayashi S, Fujii $Y$, Iwase $\mathrm{H}$, Yamashita $\mathrm{H}$ : Prognostic significance of insulin-like growth factor binding protein (IGFBP)-4 and IGFBP-5 expression in breast cancer. Jpn J Clin Oncol 2007, 37:575-582

97. Miyake H, Pollak M, Gleave ME: Castration-induced up-regulation of insulin-like growth factor binding protein-5 potentiates insulin-like growth factor-I activity and accelerates progression to androgen independence in prostate cancer models. Cancer Res 2000, 60:3058-3064.

98. Stolf BS, Carvalho AF, Martins WK, Runza FB, Brun M, Hirata R Jr, Jordão Neves E, Soares FA, Postigo-Dias J, Kowalski LP, Reis LF: Differential expression of IGFBP-5 and two human ESTs in thyroid glands with goiter, adenoma and papillary or follicular carcinomas. Cancer Lett 2003, 191:193-202.

99. Becker M, Sommer A, Kratzschmar JR, Seidel H, Pohlenz HD, Fichtner I: Distinct gene expression patterns in a tamoxifensensitive human mammary carcinoma xenograft and its tamoxifen-resistant subline MaCa 3366/TAM. Mol Cancer Ther 2005, 4:151-168.

100. Tokunaga E, Kimura Y, Oki E, Ueda N, Futatsugi M, Mashino K, Yamamoto M, lkebe M, Kakeji Y, Baba H, Maehara $Y$ : Akt is frequently activated in HER2/neu-positive breast cancers and associated with poor prognosis among hormone-treated patients. Int J Cancer 2006, 118:284-289.

101. Tokunaga E, Kataoka A, Kimura Y, Oki E, Mashino K, Nishida K, Koga T, Morita M, Kakeji Y, Baba H, Ohno S, Maehara Y: The association between Akt activation and resistance to hormone therapy in metastatic breast cancer. Eur J Cancer 2006, 42:629-635

102. Osborne CK, Shou J, Massarweh S, Schiff R: Crosstalk between estrogen receptor and growth factor receptor pathways as a cause for endocrine therapy resistance in breast cancer. Clin Cancer Res 2005, 11:865-870.

103. Akkiprik M, Nicorici D, Cogdell D, Jia YJ, Hategan A, Tabus I, YliHarja O, Y D, Sahin A, Zhang W: Dissection of signaling pathways in fourteen breast cancer cell lines using reverse-phase protein lysate microarray. Technol Cancer Res Treat 2006, 5: 543-551.

104. Perks CM, Bowen S, Gill ZP, Newcomb PV, Holly MP: Differential IGF-independent effects of insulin-like growth factor binding proteins $(1-6)$ on apoptosis of breast epithelial cells. J Cell Biochem 1999, 75:652-664.

105. Perks CM, McCaig C, Clarke JB, Clemmons DR, Holly JM: Effects of a non-IGF binding mutant of IGFBP- 5 on cell death in human breast cancer cells. Biochem Biophys Res Commun 2002, 294:995-1000.

106. Wang H, Arun BK, Wang $\mathrm{H}$, Fuller GN, Zhang W, Middleton LP, Sahin AA: IGFBP2 and IGFBP5 overexpression correlates with the lymph node metastasis in T1 breast carcinomas. Breast $J$ 2008, 14:261-267.

107. Butt AJ, Dickson KA, McDougall F, Baxter RC: Insulin-like growth factor binding protein-5 inhibits the growth of human breast cancer cells in vitro and in vivo. J Biol Chem 2003, 278: 29676-29685

108. Butt AJ, Dickson KA, Jambazov S, Baxter RC: Enhancement of tumor necrosis factor-alpha-induced growth inhibition by insulin-like growth factor-binding protein-5 (IGFBP-5), but not IGFBP-3 in human breast cancer cells. Endocrinology 2005, 146:3113-3122.

109. McCaig C, Perks CM, Holly JM: Signaling pathways involved in the direct effects of IGFBP-5 on breast epithelial cell attachment and survival. J Cell Biochem 2002, 84:784-794.

110. McCaig C, Perks CM, Holly JM: Intrinsic actions of IGFBP-3 and IGFBP-5 on Hs578T breast cancer epithelial cells: inhibition or accentuation of attachment and survival is dependent upon the presence of fibronectin. J Cell Sci 2002, 115:4293-4303.

111. Dupont J, Le Roith D: Insulin-like growth factor 1 and oestradiol promote cell proliferation of MCF-7 breast cancer cells: new insights into their synergistic effects. Mol Pathol 2001,
54:149-154.

112. Helle SI: The insulin-like growth factor system in advanced breast cancer. Best Pract Res Clin Endocrinol Metab 2004, 18: 67-79.

113. Lee AV, Weng CN, Jackson JG, Yee D: Activation of estrogen receptor-mediated gene transcription by IGF-I in human breast cancer cells. J Endocrinol 1997, 152:39-47.

114. Salerno M, Sisci D, Mauro L, Guvakova MA, Ando S, Surmacz E: Insulin receptor substrate 1 is a target for the pure antiestrogen ICI 182,780 in breast cancer cells. Int J Cancer 1999, 81: 299-304.

115. Bartucci M, Morelli C, Mauro L, Andò S, Surmacz E: Differential insulin-like growth factor I receptor signaling and function in estrogen receptor (ER)-positive MCF-7 and ER-negative MDAMB-231 breast cancer cells. Cancer Res 2001, 61:6747-6754.

116. Huynh $H$, Yang XF, Pollak $M$ : A role for insulin-like growth factor binding protein 5 in the antiproliferative action of the antiestrogen ICl 182780. Cell Growth Differ 1996, 7:1501. 1506.

117. Parisot JP, Leeding KS, Hu XF, DeLuise M, Zalcberg JR, Bach LA: Induction of insulin-like growth factor binding protein expression by $\mathrm{ICl} 182,780$ in a tamoxifen-resistant human breast cancer cell line. Breast Cancer Res Treat 1999, 55:231-242.

118. Coutts A, Murphy $\sqcup$, Murphy LC: Expression of insulin-like growth factor binding proteins by T-47D human breast cancer cells: regulation by progestins and antiestrogens. Breast Cancer Res Treat 1994, 32:153-164.

119. Pratt SE, Pollak MN: Estrogen and antiestrogen modulation of MCF7 human breast cancer cell proliferation is associated with specific alterations in accumulation of insulin-like growth factor-binding proteins in conditioned media. Cancer Res 1993, 53:5193-5198.

120. Figueroa JA, Jackson JG, McGuire WL, Krywicki RF, Yee D: Expression of insulin-like growth factor binding proteins in human breast cancer correlates with estrogen receptor status. J Cell Biochem 1993, 52:196-205.

121. Normanno N, Di Maio M, De Maio E, De Luca A, de Matteis $A$, Giordano A, Perrone F, NCl-Naple Breast Cancer Group: Mechanisms of endocrine resistance and novel therapeutic strategies in breast cancer. Endocr Relat Cancer 2005, 12:721-747.

122. Matsumoto T, Gargosky SE, Kelley K, Rosenfeld RG: Characterization of an insulin-like growth factor binding protein-5 protease produced by rat articular chondrocytes and a neuroblastoma cell line. Growth Regul 1996, 6:185-190.

123. Tanno B, Cesi V, Vitali R, Sesti F, Giuffrida ML, Mancini C, Calabretta B, Raschellà G: Silencing of endogenous IGFBP-5 by micro RNA interference affects proliferation, apoptosis and differentiation of neuroblastoma cells. Cell Death Differ 2005, 12:213-223.

124. Cesi V, Vitali R, Tanno B, Giuffrida ML, Sesti F, Mancini C Raschellà G: Insulin-like growth factor binding protein 5: contribution to growth and differentiation of neuroblastoma cells. Ann N Y Acad Sci 2004, 1028:59-68.

125. Tanno B, Vitali $R$, De Arcangelis D, Mancini C, Eleuteri $P$, Dominici C, Raschellà G: Bim-dependent apoptosis follows IGFBP-5 down-regulation in neuroblastoma cells. Biochem Biophys Res Commun 2006, 351:547-552.

126. Gregory CW, Kim D, Ye P, D'Ercole AJ, Pretlow TG, Mohler JL, French FS: Androgen receptor up-regulates insulin-like growth factor binding protein-5 (IGFBP-5) expression in a human prostate cancer xenograft. Endocrinology 1999, 140: 2372-2381.

127. Arnold JT, Le H, McFann KK, Blackman MR: Comparative effects of DHEA vs. testosterone, dihydrotestosterone, and estradiol on proliferation and gene expression in human LNCaP prostate cancer cells. Am J Physiol Endocrinol Metab 2005, 288: E573-E584.

128. Matilainen M, Malinen M, Saavalainen K, Carlberg C: Regulation of multiple insulin-like growth factor binding protein genes by 1 $\alpha, 25$-dihydroxyvitamin $\mathrm{D}_{3}$. Nucleic Acids Res 2005, 33:55215532 .

129. Xu C, Graf LF, Fazli L, Coleman IM, Mauldin DE, Li D, Nelson PS, Gleave M, Plymate SR, Cox ME, Torok-Storb BJ, Knudsen BS: Regulation of global gene expression in the bone marrow microenvironment by androgen: androgen ablation increases insulin-like growth factor binding protein-5 expression. Prostate 2007, 67:1621-1629. 
130. Kanzaki S, Hilliker S, Baylink DJ, Mohan S: Evidence that human bone cells in culture produce insulin-like growth factorbinding protein-4 and -5 proteases. Endocrinology 1994, 134: 383-392.

131. Slootweg MC, Ohlsson C, van Elk EJ, Netelenbos JC, Andress DL: Growth hormone receptor activity is stimulated by insulinlike growth factor binding protein $\mathbf{5}$ in rat osteosarcoma cells. Growth Regul 1996, 6:238-246.

132. Schneider MR, Zhou R, Hoeflich A, Krebs O, Schmidt J, Mohan S, Wolf $E$, Lahm $H$ : Insulin-like growth factor-binding protein-5 inhibits growth and induces differentiation of mouse osteosarcoma cells. Biochem Biophys Res Commun 2001, 288:435442.

133. Mohan S, Thompson GR, Amaar YG, Hathaway G, Tschesche $H$, Baylink DJ: ADAM-9 is an insulin-like growth factor binding protein-5 protease produced and secreted by human osteoblasts. Biochemistry 2002, 41:15394-15403.

134. Yin $\mathrm{P}, \mathrm{Xu} \mathrm{Q}$, Duan $\mathrm{C}$ : Paradoxical actions of endogenous and exogenous insulin-like growth factor-binding protein-5 revealed by RNA interference analysis. J Biol Chem 2004, 279: 32660-32666.

135. Amaar YG, Tapia B, Chen ST, Baylink DJ, Mohan S: Identification and characterization of novel IGFBP5 interacting protein: evidence IGFBP5-IP is a potential regulator of osteoblast cell proliferation. Am J Physiol Cell Physio/ 2006, 290:C900-C906.

136. Govoni KE, Amaar YG, Kramer A, Winter E, Baylink DJ, Mohan S: Regulation of insulin-like growth factor binding protein-5, four and a half lim-2, and a disintegrin and metalloprotease-9 expression in osteoblasts. Growth Horm IGF Res 2006, 16:49-56.

137. Hofmann J, Wegmann B, Hackenberg R, Kunzmann R, Schulz KD, Havemann K: Production of insulin-like growth factor binding proteins by human ovarian carcinoma cells. J Cancer Res Clin Oncol 1994, 120:137-142.

138. Wang H, Rosen DG, Wang H, Fuller GN, Zhang W, Liu J: Insulinlike growth factor-binding protein 2 and 5 are differentially regulated in ovarian cancer of different histologic types. Mod Pathol 2006, 19:1149-1156.

139. Walker G, MacLeod K, Williams AR, Cameron DA, Smyth JF, Langdon SP: Insulin-like growth factor binding proteins IGFBP3, IGFBP4, and IGFBP5 predict endocrine responsiveness in patients with ovarian cancer. Clin Cancer Res 2007 , 13:1438-1444.

140. Miyatake T, Ueda Y, Nakashima R, Yoshino K, Kimura T, Murata T, Nomura T, Fujita M, Buzard GS, Enomoto T: Down-regulation of insulin-like growth factor binding protein-5 (IGFBP-5): novel marker for cervical carcinogenesis. Int J Cancer 2007, 120: 2068-2077.

141. Gao XQ, Han JX, Huang HY, Song B, Zhu B, Song CZ: Effect of NS398 on metastasis-associated gene expression in a human colon cancer cell line. World J Gastroenterol 2005, 11: 4337-4343.

142. Fenton JI, Lavigne JA, Perkins SN, Liu H, Chandramouli GV, Shih $\mathrm{JH}$, Hord NG, Hursting SD: Microarray analysis reveals that leptin induces autocrine/paracrine cascades to promote survival and proliferation of colon epithelial cells in an Apc genotype-dependent fashion. Mol Carcinog 2007, 47:9-21.

143. Cheung C, Vesey D, Cotterill A, Douglas M, Gobe G, Nicol D, Johnson D: Altered messenger RNA and protein expressions for insulin-like growth factor family members in clear cell and papillary renal cell carcinomas. Int $J$ Urol 2005, 12:17-28.

144. Takahashi M, Papavero V, Yuhas J, Kort E, Kanayama HO, Kagawa S, Baxter RC, Yang XJ, Gray SG, Teh BT: Altered expression of members of the IGF-axis in clear cell renal cell carcinoma. Int J Oncol 2005, 26:923-931.

145. Liu Y, Sun W, Zhang K, Zheng H, Ma Y, Lin D, Zhang X, Feng L, Lei W, Zhang Z, Guo S, Han N, Tong W, Feng X, Gao Y, Cheng $S$ : Identification of genes differentially expressed in human primary lung squamous cell carcinoma. Lung Cancer 2007, 56: 307-317.

146. Yi HK, Hwang PH, Yang DH, Kang CW, Lee DY: Expression of the insulin-like growth factors (IGFs) and the IGF-binding proteins (IGFBPs) in human gastric cancer cells. Eur J Cancer 2001, 37:2257-2263.

147. Johnson SK, Dennis RA, Barone GW, Lamps LW, Haun RS: Differential expression of insulin-like growth factor binding protein-5 in pancreatic adenocarcinomas: identification using DNA microarray. Mol Carcinog 2006, 45:814-827. 